\title{
"Os perfumes, as cores e os sons se correspondem": Benveniste e a busca pela imagem criativa em Baudelaire
}

Sabrina Vier*

\section{Resumo}

Em 1992, manuscritos de Émile Benveniste sobre a linguagem poética foram anunciados e geraram o que hoje se conhece como Dossiê Baudelaire. Este estudo objetiva verificar como a escrita de Benveniste presente no dossiê esboça um estudo semiológico de uma obra. O corpus são 159 fólios que deixam ver termos e procedimentos ruminados na escrita de Benveniste. Os resultados apontam que a particularidade e a singularidade do discurso de Baudelaire devem-se à imagem do espelho, que engendra outras imagens criativas. A correspondência é, então, o princípio que estrutura o universo poético baudelaireano.

Palavras-chave: Semiologia. Dossiê Baudelaire. Imagem criativa.

\section{Introdução}

Em 2008, via tese de Chloé Laplantine, e em 2011, via editora Lambert-Lucas, manuscritos de Benveniste sobre a língua poética de Baudelaire vieram a público: trata-se do Dossiê Baudelaire - um conjunto de manuscritos que apresenta notas de todos os tipos, planos, vestígios de planejamento, interrogações escritas pelo linguista (FENOGLIO, 2013). O Dossiê Baudelaire é composto por 367 fólios que estão conservados no departamento de manuscritos da Biblioteca Nacional da França em uma pasta azul com elástico. Dentro da pasta azul com elástico, é possível abrir uma outra pasta de papelão cinza esverdeado, na qual está escrito, no canto superior direito, pela mão de Benveniste, Baudelaire (LAPLANTINE, 2011).

\footnotetext{
Doutora em Linguística Aplicada. Professora convidada no Mestrado Profissional em Gestão Educacional - Unisinos. E-mail: sabrinavier@hotmail.com
}

Data de submissão: set. 2018 - Data de aceite: out. 2018 http://dx.doi.org/10.5335/rdes.v14i3.8587 
Em 1969, no artigo Semiologia da Língua, Benveniste pensa a relação entre sistemas semiológicos distintos. E é neste artigo, e somente neste artigo, que o linguista apresenta um verso de um poema de Baudelaire para explicar uma das relações possíveis entre sistemas distintos:

"Os perfumes, as cores e os sons se correspondem". Estas “correspondências" não estão senão em Baudelaire, elas organizam seu universo poético e a imagem que o reflete (BENVENISTE, 1969/2008, p. 61).

Pontuo aqui que faço uso da versão em francês: "[...] et l'imagerie qui le reflete" (BENVENISTE, 1969/2008, p. 61). Isso porque a versão brasileira apresenta "[...] e a criação que o reflete" (BENVENISTE, 1969/1989, p. 62), desconsiderando a "imagem" - termo essencial no estudo empreendido pelo linguista que se deixa ver nesses manuscritos.

Também em suas últimas aulas encontramos uma anotação que versa sobre o poeta: "Baudelaire intuiu essa relação de homologia em seu poema Correspondences" [grifo do autor] (BENVENISTE, 2014, p. 190). Essa relação de homologia coloca em cena que os perfumes, as cores e os sons, se tomados como sistemas distintos, não apresentam, pois, uma relação plena: a relação entre eles será estabelecida por quem ler o poema. Nesse ponto, Benveniste (1969/1989, p. 62) conclui:

[...] a homologia instaurada servirá de princípio unificador entre dois domínios e limitar-se-á a esse papel funcional, ou ela criará uma espécie de valores semióticos. Nada assegura antecipadamente a validade desta relação, nada limita sua extensão.

Segundo Flores (2013), a relação de homologia - uma das relações entre sis- temas semiológicos distintos - não é da ordem da constatação - como no caso da relação de engendramento, em que podemos constatar que o alfabeto comum gerou o alfabeto braile -, mas da instauração: "[...] ela é estabelecida por quem analisa os sistemas. Nesse sentido, o analista está implicado no estabelecimento dessas relações" (FLORES, 2013, p. 185), relações estas instauradas "[...] em virtude de conexões que se descobrem ou que se estabelecem entre dois sistemas distintos" (BENVENISTE, 1969/1989, p. 62).

Há, para estabelecer uma relação de homologia, a necessidade de uma relação de interpretância, que é estabelecida entre sistema interpretante e sistema interpretado, sendo a língua o interpretante de todos os sistemas semiológicos. A língua comporta ao mesmo tempo a significância dos signos e a significância da enunciação. E nesse sentido Benveniste aponta o poder maior da língua a partir da relação de interpretância:

[...] o de criar um segundo nível de enunciação, em que se torna possível sustentar propósitos significantes sobre a significância (BENVENISTE, 1969/1989, p. 66).

Pelas indicações presentes em $\mathrm{Se}$ miologia da Língua e nas anotações das últimas aulas, Benveniste buscava, no que podemos encontrar de sua escrita presente no Dossiê Baudelaire, a homologia intuída por Baudelaire. Para poder instaurar homologias, o linguista escreveu sobre essa relação, estabelecendo uma interpretância. E que homologias foram instauradas pelo linguista nesse estudo?

A fim de responder a essa questão, proponho a sequência deste espaço de fala 
em três itens. No primeiro, esclarecerei de que forma busco as relações de interpretância que Benveniste produziu em sua escrita, ou seja, apresentarei uma possibilidade de leitura dos manuscritos presentes no Dossiê Baudelaire. Em seguida, compartilho um percurso de leitura em busca da imagem que reflete o universo poético de Baudelaire. Por último, pontuo de que maneira esse estudo empreendido por Benveniste pode ser pensado como um estudo semiológico de uma obra literária.

\section{Um percurso de leitura}

Consoante Laplantine (2008, 2009, 2011a), o Dossiê Baudelaire comporta um estudo que objetivava a escrita de um artigo. Essa hipótese se deve ao fato de que Benveniste tinha o hábito de fazer listas dos livros ou artigos que pretendia escrever: "Em uma dessas listas, que data de 1967, pode-se ler: 'Langages/ (A língua de Baudelaire)" (LAPLANTINE, 2011a, p. 8). Sabe-se, hoje, que esse artigo foi solicitado por Roland Barthes que organizou o número 12 (publicado em dezembro de 1968) da revista Langages, intitulada Linguística e literatura. No entanto, esse artigo jamais foi publicado ou mesmo posto em rascunho (LAPLANTINE, 2011b).

Fenoglio (2009, 2013), linguista-geneticista que estudou a fundo diferentes manuscritos de Benveniste, esclarece que um rascunho é possibilidade de um artigo; no entanto, entre os fólios do dossiê, não há rascunho: há somente notas, e notas não geram artigos. Ou seja, o que encontramos nas notas não podem ser tomadas com o mesmo estatuto que toma- mos os artigos publicados nos Problemas de Linguística Geral, por exemplo.

Recorrendo aos estudos da linguista-geneticista, é possível observar quatro movimentos enunciativos do linguista quando escreve notas: espaço para interrogações metodológicas, para realizar anotações pessoais sobre o processo de escrita, para validar noções por ele trabalhadas ou para anotar aspectos relevantes da formação do pensamento teórico (FENOGLIO, 2009). Fenoglio (2013) acredita que, no Dossiê Baudelaire, é possível encontrar traços da formação do pensamento teórico do linguista, mas ainda em processo, do que ela denomina, de ruminação enunciativa: uma escrita que deixa ver que Benveniste fazia várias versões do mesmo conteúdo, em um espaço para a escrita espontânea, ou seja, para o pensamento teórico em construção (FENOGLIO, 2009). Dito de outra forma, no espaço-tempo das notas, Benveniste pensa; no espaço-tempo do rascunho, ele escreve para a leitura dos outros (FENOGLIO, 2013).

Para tomar o Dossiê Baudelaire como objeto de estudo, há, pois, a necessidade de ler o material a partir dessa perspectiva, a da ruminação enunciativa. Nesse sentido, traço, para este artigo, o seguinte percurso que visa levar em conta a ruminação presente nos fólios em estudo: observar a partir dos traços de Benveniste - repetições, rasuras, inserções - como os termos e os procedimentos tornam e retornam em sua escrita; estabelecer correspondências entre cada grupo de notas reunidas em função da ruminação deflagrada; derivar dessa correspondência uma reflexão; evidenciar de que forma 
essa reflexão diz da imagem como reflexo do universo poético de Baudelaire.

\section{O fólio 323 como ponto de partida}

Neste artigo, utilizarei, para apresentação dos fólios, a transcrição diplomática em tradução para o português brasileiro. Nessa transcrição, conforme Laplantine (2011), preservam-se a cor da caneta utilizada por Benveniste e os grifos por ele realizados - o que interessa para colocar a ruminação enunciativa em estudo. Além disso, aparecem, no final da transcrição, o número do envelope, a numeração do fólio no envelope e a numeração do fólio em relação ao número total de fólios.

O único fólio datilografado, o 323, é o ponto de partida deste estudo. Conforme Fenoglio (2009), que analisou os movimentos de escrita de Benveniste, esta é a forma mais próxima do texto a ser publicado: a versão datilografada.

O discurso poético.

Na língua comum, o discurso é o discurso do pensamento da demonstração, do raciocínio, por mais resumido que seja. O discurso poético não tem nada além do aparelho do discurso. A matéria é a experiência vivida do poeta, seu devaneio, sua visão. Não há mensagem, mas uma emoção suscitada no leitor.

Há certamente o fato de que o discurso poético utiliza esses mesmos processos linguísticos, a mesma matéria linguística que o discurso usual Mas temos toda certeza? Quem nos prova que se trata da mesma língua? A identidade material do vocábulo "claro" em "está claro" e em "diadema deslumbrante e claro" é um dado de fraco interesse quando tal distância separa estes dois empregos. Não hesitaremos em dizer que o material da língua poética é distinto, como são distintas a dicção poética e a fonética poética. Será bom, em todo caso, tomar como hipótese de trabalho o caráter radicalmente específic[o] da língua poética em todos os seus aspectos e em sua estrutura inteira.

Consideremos agora o discurso em Baudelaire. Quem o lê com a preocupação de ver como se caracteriza esse discurso em Baudelaire deve logo desistir. Numerosas são as confissões dos críticos: só se sabe dizer deste discurso que nada o distingue de todos os outros. Não se vê como é feito. Parece que Baudelaire sob este ponto de vista não se distingue de Hugo. Nada além de tradicional nele. Mesmo Bonnefoy faz essa constatação decepcionante e desencorajadora.

Há muito partilho desse sentimento. O que contudo me impediu de me desesperar e desistir foi a conviç̧ão de que ele deveria ter alguma coisa de particular, e mesmo de única em seu discurso. Essa convicção não se fundava senão sobre um argumento que era - singularmente - mais de lógica do que de sentimento: se essa alguma coisa não existisse, mesmo no discurso aparente no diseurso mais regular e "prosaico" de Baudelaire, toda a estrutura poética da obra inteira (22, fำ 71/ fo 323 ). 
Chama atenção neste fólio o verbo "consideremos": haveria aqui um convite ao leitor para problematizar algo? Benveniste considera, pois, um aspecto e institui o leitor como interlocutor desse processo de investigação? Nunca teremos de fato as respostas a essas questões; no entanto, Fenoglio (2012) destaca que o "nós" aponta, sim, para a publicação de um texto, pois essa era a marca científica da época.

Nesse fólio, o linguista aborda, primeiramente, o discurso poético, problematizado pelo discurso da língua comum para, em seguida, pensar o discurso em Baudelaire. Esse percurso poderia ser assim traçado: há questões cruciais quando se pensa o discurso na língua comum e o discurso na língua poética. Que língua é essa presente no discurso poético? Será a mesma língua encontrada no discurso da língua comum? Benveniste responde a essas duas questões: o material da língua poética é distinto do material da língua comum. A língua poética apresenta, pois, um caráter radicalmente específico em todos os seus aspectos e em sua estrutura inteira. Nesse ponto, Benveniste convida o leitor a considerar o discurso em Baudelaire em sua especificidade. $\mathrm{O}$ linguista parece ter "[...] a convicção de que ele [Baudelaire] deveria ter / alguma coisa de particular, e mesmo de única em seu discurso" (22, f $\mathrm{f}^{\mathrm{0}} 71$ / $\left.\mathrm{f}^{\mathrm{o}} 323\right)$. Gostaria, primeiramente, de problematizar os dois atributos dados ao discurso de Baudelaire: particular e único.
O discurso visto como particular o coloca como oposto ao discurso geral: uma coisa que é da ordem do particular apresenta características de uma determinada pessoa. Se o discurso é a atualização que cada um faz da língua, haveria um discurso geral? Não. Nesse sentido, Benveniste delimita em sua escrita que o discurso é sempre de Baudelaire e não um discurso em Baudelaire.

O discurso visto como único o coloca como diferente do discurso dos outros: uma coisa é única quando apresenta características singulares. Se o discurso é a atualização que cada um faz da língua, ele não seria desde sempre singular? Sim. Nesse viés, a convicção que Benveniste aponta e sublinha em "deveria" diz do discurso de Baudelaire porque diz do discurso do homem na língua.

Temos aqui dois pontos importantes: a língua de Baudelaire e o discurso de Baudelaire. Sobre o primeiro, Benveniste escreve que a língua de Baudelaire é a mesma língua do uso cotidiano, mas sua materialidade, bem como sua dicção e fonética, não são as mesmas. Para estudar o discurso particular e único de Baudelaire, é preciso, pois, investigar, primeiramente, a materialidade que o constitui. E o que Benveniste escreveu sobre essa investigação? Foquemos em outros dois fólios: 


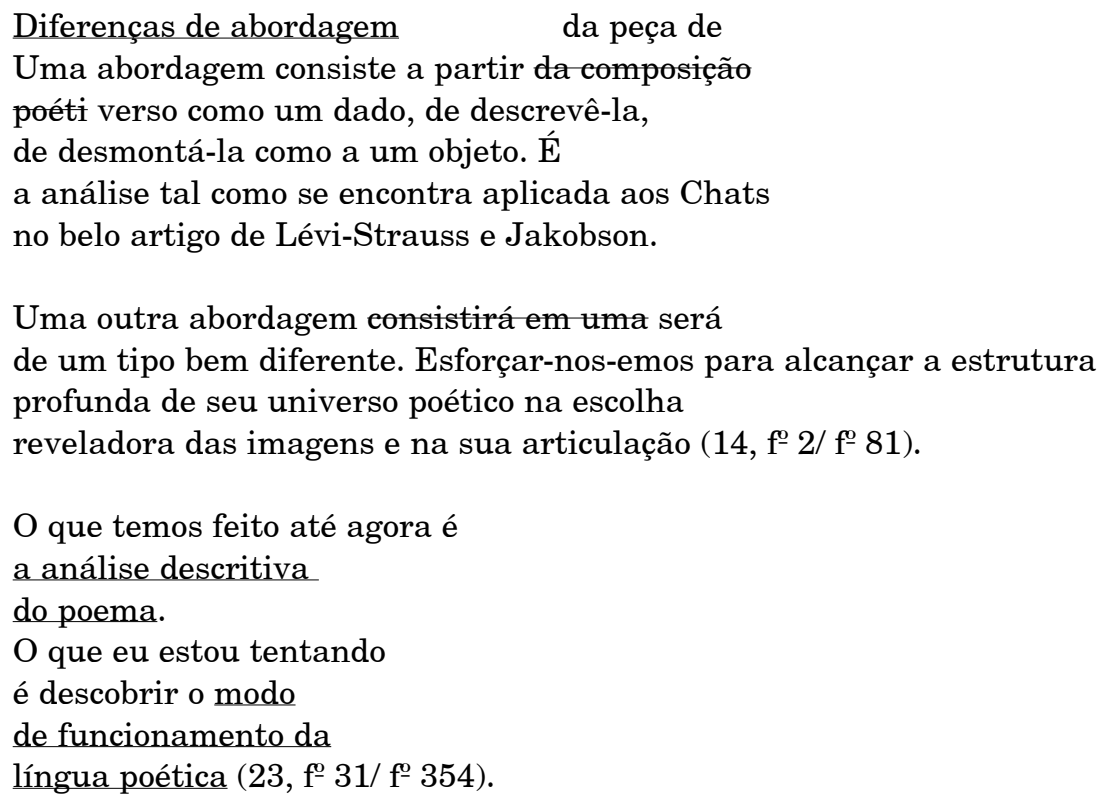

Há nesses fólios, pelo menos, duas perspectivas diferentes de pesquisa:

a) a primeira descreve o poema, desmontando-o como a um objeto;

b) a segunda investiga a escolha das imagens e a sua articulação, buscando a estrutura profunda do universo poético.

Benveniste marca-se na segunda perspectiva, "eu estou tentando é descobrir o modo de funcionamento da língua poética", e não na primeira, descrever os versos dos poemas. Isso porque se o poema é espaço para o discurso de Baudelaire, ele não apresenta algo dado, suscetível de descrição, mas algo instaurado a partir das relações possíveis entre escrita e língua.
A segunda perspectiva marca-se como uma busca completamente diferente do que se fazia até então: investigar não é descrever. Investigar está para instauração; descrever está para a coleta de dados. E a instauração de um percurso está para a busca de homologias. A partir do fólio 323, coloquei em estudo, então, os demais fólios, buscando por ruminações enunciativas que colocassem em cena (i) a particularidade e a singularidade do discurso de Baudelaire e (ii) o caráter radicalmente específico da língua poética.

Neste artigo, compartilharei o resultado das ruminações acerca da particularidade e da singularidade do discurso de Baudelaire: as imagens criativas e sua articulação em As Flores do Mal. 


\section{As imagens e sua articulação}

Com a descrição "Parte da frente de papel timbrado da Société de Linguistique de Paris", encontramos uma sequência de cinco fólios numerados - em seu canto superior direito - de 1 a 5 (fólios 11, 12, 13, 14 e 15). Os três primeiros têm como título Condições formais da poesia e os dois últimos Processos. Na quinta nota, o fólio 15, o linguista escreve que em Baudelaire a grande imagem é a do "anjo" e também a do "satanás". Nesse ponto, coloca entre parênteses uma observação:

$[\ldots]$

(Nota: procurar as imagens criadoras, os esquemas que se engendram, e ver como eles se produzem e que estrutura eles constituem).

uma grande fonte: perfume, odor, se evapora.

(mas não prata)

joias pedra Jou bijuterias

outra fonte: metais pedrarias, pérolas (os inexoráveis diamantes

esplendores ocultos, mudos, insensíveis ) crisóis, cobre

[27 onde tudo é ouro, aço, luz e diamantes - brilho de metal e de pedra ]

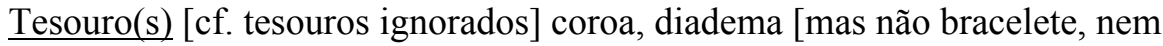
aliança, nem anel]

e as imagens da luz que recai sobre essas matérias preciosas relâmpago, clarão, cintilação, brilha lantejoula, irradiar $\left(8, f^{0} 5 /\right.$ f $\left.^{0} 15\right)$.

Nesse fólio, Benveniste anota que há, pelo menos, três fontes dessas imagens, ligadas ao odor, ao metal e à luz. Em relação às fontes, o linguista registra algumas palavras presentes nos poemas e que estão relacionadas a essas fontes, conforme podemos ver no excerto apresentado. Seriam as palavras, então, as fontes dessas imagens?
No fólio 18 , o linguista risca a palavra "imagem" e anota em seu lugar "sensação geradora" para falar do odor, da visão e do movimento - termos bastante próximos ao que vimos no fólio 15 . Observemos essa rasura: 


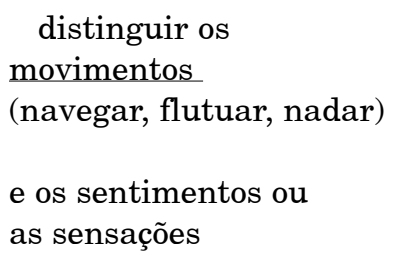

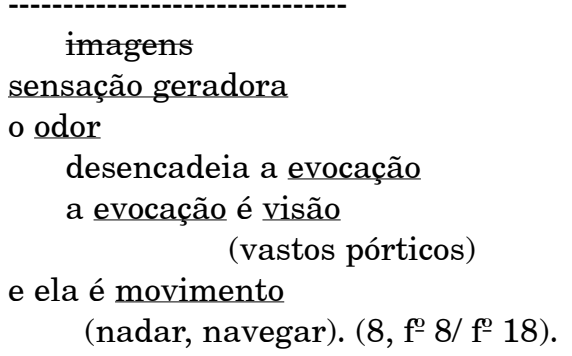

Aqui há a anotação de que é preciso distinguir os movimentos e as sensações: o odor, por ser uma sensação geradora, suscita uma evocação que, por sua vez, é visão e movimento. Há, então, algo que é imagem e algo que é sensação geradora nos poemas de Baudelaire? Tratam-se de dois sistemas diferentes?

Benveniste volta ao odor no fólio 128 , quando escreve que Baudelaire é o poeta que mais teve êxito na fusão dos sentidos, pois o perfume suscita os outros sentidos. Nesse ponto, o linguista anota os poemas XII, Perfume exótico, e XXIII, A cabeleira.
Neste último, encontramos na quarta estrofe os versos "Um porto em febre/ A grandes goles o perfume, o som e a cor" (BAUDELAIRE, 2006, p. 165). Seriam esses versos uma mostra da fusão sobre a qual escreve Benveniste no fólio 128 ?

Essa hipótese encontra no fólio 79, intitulado de Extraordinário fervilhar de imagens, uma possível resposta: Benveniste volta a citar os poemas XII e XXIII para escrever que é o odor que suscita e guia "[...] o perfume, o som e a cor". Por que será que no título dessa nota encontramos a palavra "extraordinário"? O que seria extraordinário para Benveniste? Seria o odor ou a imagem que fervilha nos poemas de As Flores do Mal?

Da forma como leio a escrita presente no Dossiê Baudelaire, o extraordinário estaria para o fervilhar de imagens, sendo o odor uma delas. Isso porque Benveniste parece encantado com o grande número de imagens nos poemas e com a própria existência da imagem nos poemas.

Voltemos ao odor. $O$ odor é justamente o título do fólio 41, em que o linguista escreve:

\section{Além dos termos diretamente relacionados com: odor, perfume, odor agradável, anotar que impregna somente o que visa ao odor: \\ Ele registra as metáforas, comparações, geradas pelo odor (10, fo ${ }^{-0}$ / fo 41$)$.}

Aimagem odor não aparece somente a partir da palavra “odor”, mas também a partir de metáforas e comparações geradas pelo odor. E o que isso diz da escolha reveladora de imagens? A imagem está também na metáfora e na comparação?
Foquemos no fólio 19, transcrito abaixo, em que o linguista descarta um parágrafo inteiro em que a palavra "imagem" está presente e o reescreve: 


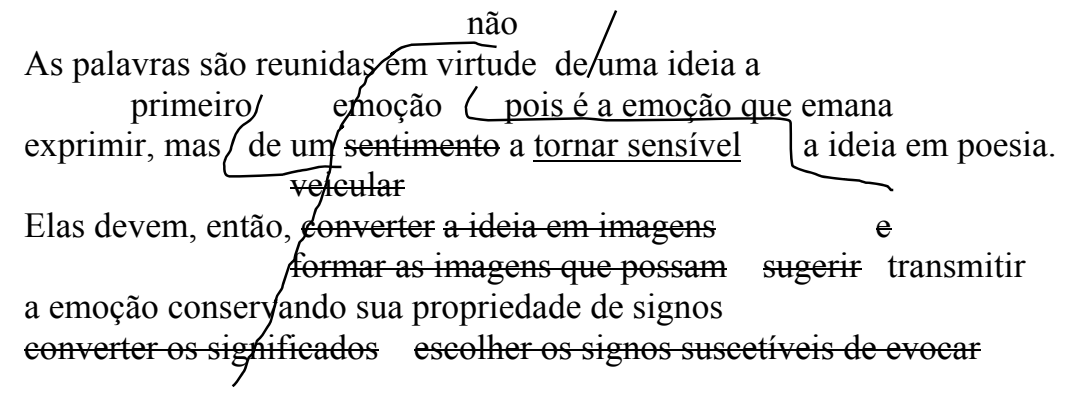

As palavras são escolhidas e reunidas não em virtude não primeiro

de uma ideia a enunciar, mas de uma emoção a tornar sensível, pois é aos sentidos que elas se dirigem primeiro: e é da emoção que emana a ideia em poesia. As palavras devem então A mensagem é então primeiro

de comunicar uma

um diseurse encarregada A emoção. As palavras devem formar as imagens adequadas para despertar a emoção e no entanto agir em sua qualidade de signos. Aí está o nó do problema: a relação do representado ao significado $\left(8, \mathrm{f}^{\circ}\right.$ 9/ fo 19$)$.

Em um primeiro momento, gostaria de destacar que a escrita de Benveniste nesse fólio coloca em cena a relação estreita entre a palavra, a emoção e a imagem. Para falar delas, o linguista descarta as três construções que seguem:

a) Elas [as palavras] devem então veicular

b) Elas [as palavras] devem então converter a ideia em imagens

c) Elas [as palavras] devem então formar as imagens que possam sugerir

Essas construções teriam como complemento "a emoção". Na anotação reescrita, encontramos "As palavras devem então" para em seguida aparecer riscada novamente. No entanto, essa construção reaparece no final do fólio: "As palavras devem formar as imagens adequadas para despertar a emoção".

Entre a construção descartada e a reescrita, Benveniste anota:

palavras devem entãe A mensagem é então primeiro ¿de comunicar uma」

um diseurse encarregada

O que aqui aparece é uma insistência sobre o papel da palavra em As Flores do $M a l$. E essa insistência parece buscar o termo adequado para isso. Descarta-se, num primeiro momento, que a palavra possa "veicular", "converter" ou "formar" a emoção. Em seguida, volta-se a escrever "formar", mas para registrar que as palavras formam as imagens: 
As palavras devem

formar as imagens adequadas para despertar a emoção

e no entanto agir em sua qualidade de signos.

O que o excerto acima apresenta é que as palavras formam as imagens e que as imagens despertam a emoção. A palavra não forma a emoção: a palavra desperta a emoção. E como despertar essa emoção no leitor? Através das palavras que formam imagens. Imagens essas que devem ser construídas para suscitar a emoção. Emoção é, então, o ponto de partida e o ponto de chegada da palavra na poesia. E o intermediário desse percurso é a imagem.

Em relação à emoção, encontramos, no fólio 138, um excerto de William Carlos Williams. Esse trecho é parte de uma resposta à questão "Sr, Williams, o senhor poderia me dizer, de forma simples, o que é poesia?" presente na obra Paterson:

\begin{abstract}
Poesia
"A poesia é uma linguagem carregada de emoção. De palavras organizadas ritmicamente" (William Carlos Williams, Paterson) citada na Critique $\mathrm{n}^{\circ} 235$ (dez 1966) p. 1008-9.

Como resultado, estes são os dois critérios essenciais: 1) organização rítmica, quadro formal prévio - 2) linguagem carregada de emoção - ordem semântica específica (17, fo 17/ fo 138).
\end{abstract}

Benveniste volta à primeira frase de Williams mais quatro vezes no DB: no fólio 50 , ao afirmar que tudo na poesia deve ser definido, avaliado e classificado mediante o critério da emoção; no fólio 197, ao abordar que a originalidade do discurso de Baudelaire é ter uma linguagem carregada de emoção; no fólio 250 , ao apontar a poesia como uma linguagem única porque carregada de emoção; e no fólio 308 , ao escrever que o sentido poético advém da linguagem carregada de emoção. Há aqui uma insistência para marcar que a poesia é uma linguagem de emoção - ordem semântica específica - organizada ritmicamente - quadro formal prévio.

E como essa emoção é suscitada na poesia? A partir das imagens organizadas ritmicamente. Benveniste torna e retorna muitas vezes à relação entre a imagem e a emoção. Destaco aqui sete fólios em que o linguista rumina sobre essa questão: 
[...] Essa emoção nasce de uma experiência profunda, única, do mundo. O poeta não pode libertar-se de sua experiênciaobsessão, que cada incidente de sua vida renova, a não ser exprimindo-a por meio de imagens. Sua linguagem deve

$$
\text { o vivido }
$$

re-presentar,re-produzir a emoção: a imagem é o intermediário necessário da emoção, e como é sonoridade, a língua deve encontrar os sons que a evocam. A linguagem do poeta será, então, de todos os pontos de vista, uma linguagem icônica $\left(6, \mathrm{f}^{\mathrm{o}} 4 / \mathrm{f}^{\mathrm{o}} 4\right)$.

[...] O poeta transmite a experiência, ele não a descreve:

"Nós morremos a cada instante"

ele dá a emoção, não a ideia da emoção.

A tarefa e do poeta é essa experiência

transcrever essa emoção em uma forma de em imagens a enunciar em ideia

linguagem que ele evoca sem a transerever e nesses signos seletivos e nesses sintagmas específicos.

A comunicação poética consiste em comunicar a emoção associada às palavras que a portam e que a iconizam (12, fo $\left.4 / \mathrm{f}^{\circ} 56\right)$.

[...] É como uma objetivação da experiência mais íntima; a emoção é convertida ou extrovertida em imagens de um mundo que tem as aparências de um mundo real: é um mundo que consiste em mares e em (22, fo $\left.11 / \mathrm{f}^{\mathrm{o}} 263\right)$. 
astros, em noites e em perfumes, em joias e em mulheres. Mas o essencial é que: essa realidade é resultado de sua emoção, não faz mais do que the dar aparências sensíveis à experiência, de um sofrimento ou de um êxtase, a um sofrimento que é êxtase.

Portanto devem-se abordar as palavras-chave dessa imaginação de realidade, desse universo recriado pela sensibilidade para retornar até seu princípio, que é a vibração toda interior de uma emoção. Pode-se assim configurar o universo dessa segunda realidade, dessa realidade que não passa de sensação e emoção transliterada em paisagens, em movimentos e em relações. $\left(22, \mathrm{f}^{\mathrm{o}} 12 / \mathrm{f}^{\mathrm{o}} 264\right)$.

[...] Em Baudelaire, como disse, a emoção se converte em imagens sensíveis, se dá um suporte sensorial, encontra sua equivalência nos objetos que a suscitam (céu noturno) ou nos movimentos que a prolongam (nado, planar, balanços) e termina por (22, fo $\left.13 / \mathrm{f}^{\mathrm{o}} 265\right)$.

ou ultramundo

instituir um verdadeiro contramundo, que se presta ao inventário e à descrição. [...] (22, fo 14/ fo 266). 
* p. ex.

quando

procuramos

nos exprimir

exatamente,

temos uma

"significação"

no espírito e

buscamos as

palavras

adequadas.
[...] A emoção é convertida em

pensamento e este pensamento por sua vez é convertido em

palavras. É um segundo pensamento, de qualquer maneira,

um pensamento representando a conceitualização de uma emoção.

Isso talvez ajude a chegar ao centro do

problema linguístico. O pensamento não se converte

imediatamente em palavras: ele deve primeiro

se converter em significação *, que e essas signi-

ficações encontram as palavras adequadas. Ou em

Baudelaire - e aí está a grande originalidade de

sua poesia, são as emoções que se conver-

tem em significações, e essas significações

levam às formulações verbais que a nós

as restituem e nos fazem compartilhar as emoções

do poeta.

Esta é a lei da língua poética:

forjar as significações intermediárias entre

a emoção e a expressão, as significações onde se

moldam as visões emotivas. $\left(20, \mathrm{f}^{\mathrm{o}} 6 / \mathrm{f}^{\mathrm{o}} 200\right)$.
A partir desses fólios, leio que a imagem é a expressão da emoção, que nasce de uma experiência do poeta. Encontramos a relação entre emoção e experiência marcada tanto no fólio 4 quanto no fólio 56 , em que Benveniste justamente acrescenta o termo experiência à anotação que faz. A emoção retorna no fólio 263 como a experiência mais intima e no fólio 264 como a experiência de um sofrimento ou de um êxtase. Há aqui uma insistência na relação estreita entre emoção e experiência no poema.

De maneira bastante didática, o linguista escreve no fólio 200 sobre a emoção e a experiência. De certa forma, é como se esse fólio reunisse os anteriores em busca dessa relação. Primeiramente, a emoção nasce de uma experiência, sendo que o poeta está preso a essa experiência, pois é a sua experiência, aquilo que o constitui. Em seguida, a emoção é convertida em pensamento, que, por sua vez, é convertido em palavras. As palavras são, então, um pensamento segundo, pois representam a conceitualização da emoção. Nesse ponto, Benveniste escreve que há aqui um problema linguístico: o pensamento não se converte logo em palavras, mas em significação.

A partir desse raciocínio, o linguista anota a originalidade de Baudelaire: é a emoção que se converte em significação e não o pensamento, por isso que a imagem em As Flores do Mal é a expressão da emoção do poeta - a imagem não diz um pensamento sobre a emoção, ela dá a 
emoção conforme escrito no fólio 56. Isso aparece também anotado no fólio 138 como um dos dois critérios específicos da poesia: "2) linguagem carregada de emoção - ordem semântica específica".

E qual o lugar da palavra nessa especificidade? Num primeiro momento, no fólio 4, Benveniste escreve que a palavra, a partir do som, é responsável por evocar essa emoção. Em seguida, no fólio 56 , a palavra também aparece como evocante da emoção e vai além: as palavras portam e iconizam ${ }^{1}$ a emoção. Ao que o linguista conclui no fólio 264:

Portanto devem-se abordar as palavras-chave dessa imaginação de realidade, desse universo recriado pela sensibilidade para retornar até seu princípio, que é a vibração toda interior de uma emoção. Pode-se assim configurar o universo dessa segunda realidade, dessa realidade que não passa de sensação e emoção transliterada em paisagens, em movimentos e em relações. ( 22 , fo 12 / fo 264 ).

Para chegar à emoção, é preciso abordar-portanto - as palavras-chave. $\mathrm{E}$, a partir dessa abordagem, pode-se - assim - configurar o universo dessa segunda realidade, resultante da emoção e representada pela escrita a partir de paisagens, movimentos e relações.
Nesses sete fólios, de forma geral, entendo que Benveniste anota que a escolha da imagem em As Flores do Mal está sempre relacionada à emoção que se quer tornar sensível a partir da palavra escrita no poema. Nesse sentido, no fólio 258, o linguista escreve:

[...] Isso quer dizer que ela imita com as palavras a imagem da coisa que ela diz, e não a ideia.

Todas as palavras e as alianças de palavras são tomadas em sentido figurado. [Retomar aqui as coisas que tenho escritas sobre esse assunto em outra nota] ( 22 , fำ 6 / $\mathfrak{f}^{-}-258$ ).

Ao anotar que a língua poética oferece com as palavras a imagem da coisa que ela diz e não a ideia da coisa que ela diz, Benveniste marca o quanto a emoção - e não um pensamento sobre a emoção - é possível a partir da palavra em poesia. Isso porque se a palavra oferecesse o pensamento, ou mesmo imitasse algo - como aparece embaixo da rasura -, talvez o sentido estivesse para o representado na imagem $\mathrm{e}$ 
não para a emoção suscitada pela imagem. É justamente disto que se trata: a imagem suscita, a imagem não representa.
No fólio 188, o linguista utiliza o termo composto "palavras-imagens" para firmar a relação entre a imagem e a palavra:

Poesia

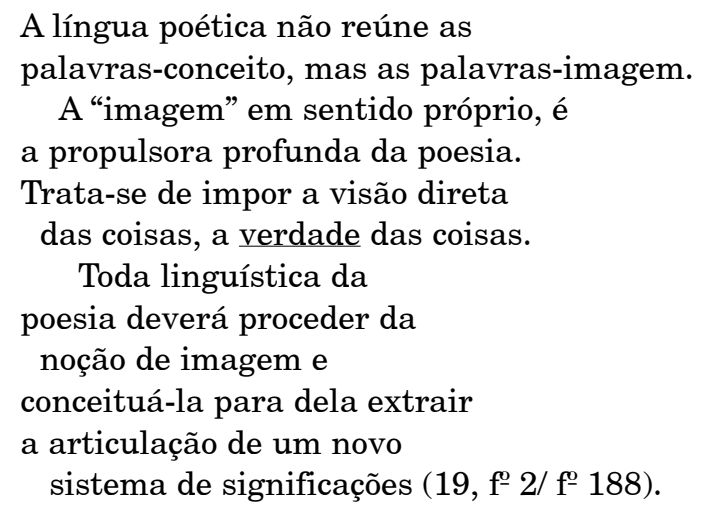

São as palavras-imagem que compõem a língua poética e não as palavras-conceito. A palavra está, pois, para a imagem e não para o conceito: a imagem é a propulsora profunda da poesia, e é a partir dela que ocorrerá a articulação de um novo sistema de significações. Isso porque, conforme anotado por Benveniste no fólio 200, as palavras de Baudelaire não representam um pensamento, mas suscitam uma emoção. E é nesse fólio que o linguista anota a lei da língua poética: "moldar as significações intermediárias entre a emoção e a expressão". De certa forma, entendemos que, para a palavra-conceito, que é o resultado do pensamento convertido em significação, já há um sistema de significações. No entanto, para a palavra-imagem, que é o resultado da emoção convertida em significação, não.
E como ocorrerá a articulação desse novo sistema de significação? A partir da imagem. Não é à toa, então, que Benveniste insiste, nos fólios 200, 264 e 265, que a emoção é convertida em imagem.

A palavra "imagem" comparece como título em seis fólios: Imagens fortes, 222; Mecanismo da Imagem Poética, 333; Imagens Motrizes, 22; As Imagens do Mar, 47; Imagens, 86; Imagens do Corpo, 94. E, pelo menos, em outros 70 fólios, a imagem aparece nas anotações do linguista. Pela maneira como Benveniste torna e retorna a esse termo, observo que o linguista escreve sob duas perspectivas:

a) levantamento de palavras-chave para pensar a escolha reveladora das imagens;

b) anotações que problematizam essa escolha. 
Iniciemos pelo levantamento. Em cinco fólios, 43, 44, 46, 48 e 49, pertencentes ao que parece ser o mesmo bloco de notas, pois todos apresentam igual descrição - "folha pequena de bloco de notas com linhas horizontais, $l=13,5, a=20,9$ ” -, há uma lista de palavras e cada palavra tem um número ao lado. Conforme verifiquei na obra em francês, esse número é o registro de sua ocorrência em As Flores do Mal. O levantamento numérico parece concluído, pois confere com o número total de ocorrências de todos os vocábulos listados pelo linguista, por exemplo:

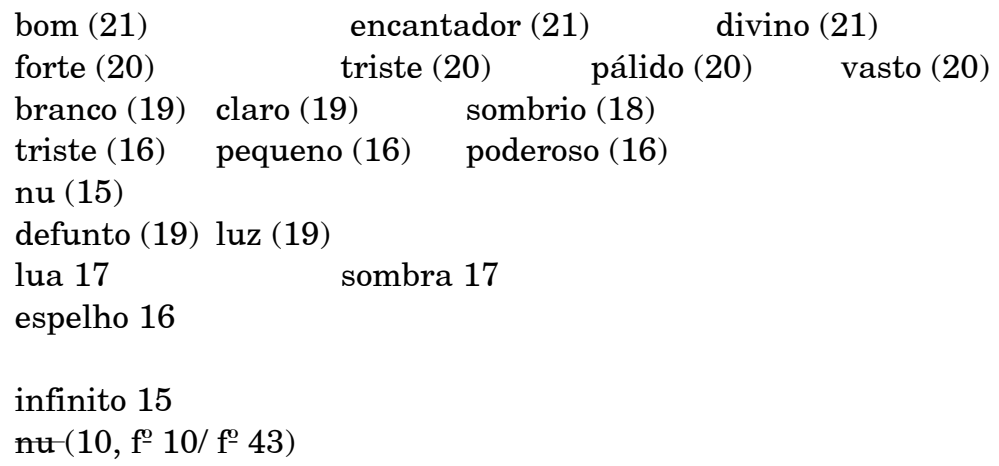

O que sabemos é que a escrita de Benveniste coloca em cena que ele estava em busca de palavras. Palavras que pudessem, talvez, formar as imagens que despertariam a emoção, conforme escrito no fólio 81: "Esforçar-nos-emos para alcançar a estrutura profunda de seu universo poético na escolha reveladora das imagens e na sua articulação".

Nos fólios 265 e 266, Benveniste escreve que

[...] a emoção se converte em imagens sensíveis [...] e termina por instituir um verdadeiro contramundo ou ultramundo, que se presta ao inventário e à descrição.
Nesse sentido, como se prestam ao inventário e à descrição, acredito que nessas listas ele estava, justamente, à procura das palavras que iconizam a emoção e a experiência.

Nas anotações que problematizam essa escolha, encontro o espelho, o mar, a água, o metal e a luz como as imagens mais ruminadas. Além destas, Benveniste também escreve sobre o ar, o amor, a mãe e a mulher. Foquemos nas mais ruminadas e na sua articulação.

No fólio 42, o linguista produz uma nota cujo título é $O$ espelho: 


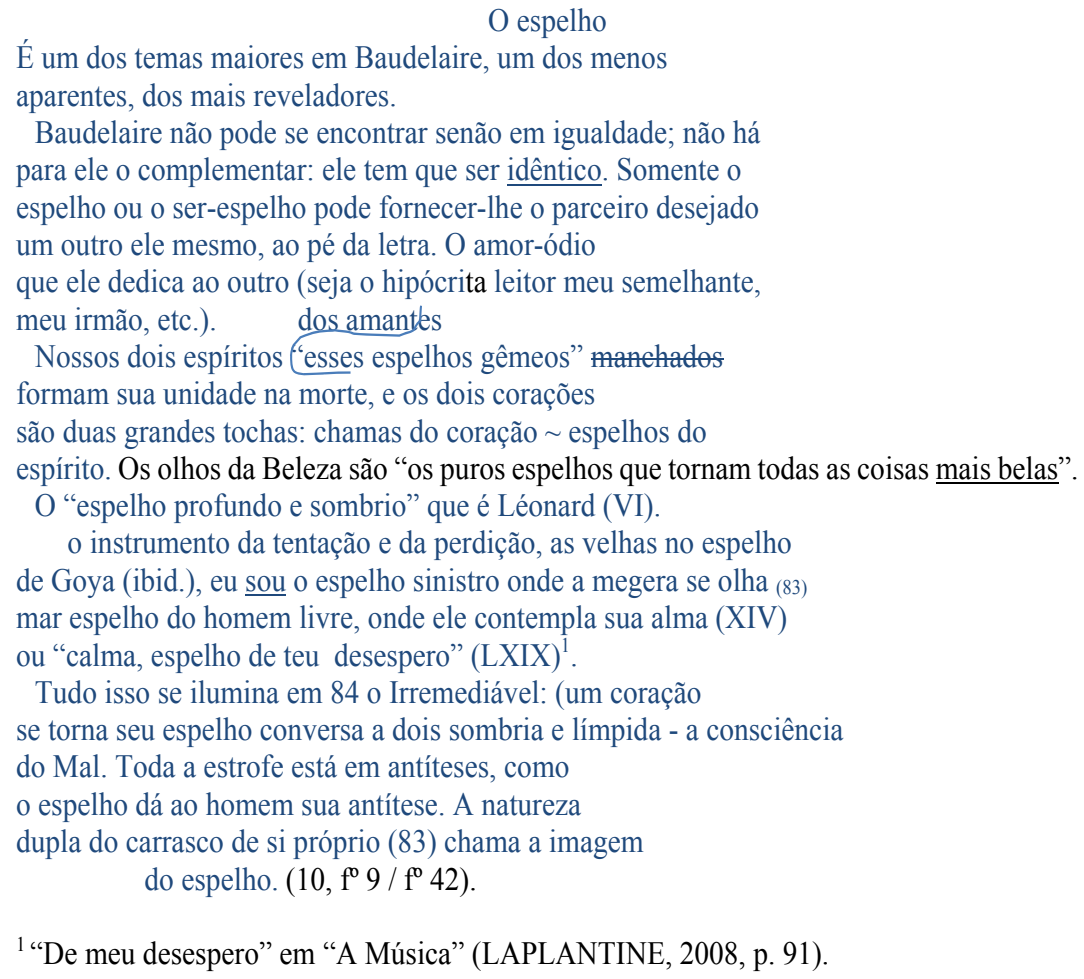

1 "De meu desespero" em “A Música” (LAPLANTINE, 2008, p. 91).

Benveniste escreve que o tema mais importante em Baudelaire, mas um dos menos frequentes, é o espelho. Na listagem de palavras, o linguista constata que a palavra "espelho" aparece 16 vezes em As Flores do Mal. E a imagem? A imagem aparece de diferentes formas. Vejamos.

Conforme o fólio 85, o espelho é uma matéria que vive em Baudelaire: "os puros espelhos que tornam as coisas mais belas". No final do fólio 97, o linguista escreve:

\section{$[\ldots]$}

Importância do espelho o outro, o semelhante, o amado - ou ou a si mesmo que se contempla e o mar se torna espelho 
No fólio 269, Benveniste novamente aborda a importância do espelho:

Tudo então em Baudelaire é correspondência e tudo tende a realizar uma harmonia:

«Correspondências » e « Harmonia » são justamente títulos de poemas.

Daí a importância da noção de espelho:

o homem e o mundo se refletem um no outro.

Daí sobretudo a equivalência, o signo de identidade colocado entre alguma coisa do homem e alguma coisa da natureza. Importância do verbo 'ser' colocada na junção como igualdade: «Vós sois um céu de outono » e em idade mais jovem: «Todos os seres amados são os jarros de fel que bebemos de olhos fechados »

Essa unidade e essa harmonia são de várias ordens:

Em Baudelaire não há objetos. As coisas não existem por si mesmas. Elas só são dadas por e para sentimentos que suscitam no homem em suas isto é ainda para as correspondências. Assim, as pedras, os metais - e a beleza feminina o movimento das inundações e da alma. (22, fo $17 /$ fo 269 ).

O que o linguista escreve aqui é que a partir da palavra "espelho", e da imagem por ela evocada, "o homem e o mundo se refletem um no outro". Ou seja, não há como separar o homem do mundo, pois um contém e está contido no outro, por isso eles se refletem. E nisso está a equivalência entre o homem e o mundo: os dois estão em relação de igualdade, um não é superior ou inferior ao outro. $\mathrm{O}$ homem e o mundo se correspondem e por isso se harmonizam a partir da imagem do espelho. Isso porque em Baudelaire o mundo não existe por si mesmo: "as coisas são dadas por e para sentimentos que suscitam no homem isto é ainda em suas correspondências". Seriam o homem e o mundo entendidos por Benveniste como dois sistemas semiológicos distintos? $\mathrm{E}$, além disso, haveria uma relação de homologia entre eles na obra As Flores do Mal?

No final do fólio 97 , conforme visto anteriormente, ao escrever sobre a importância do espelho, o linguista anota que "o mar se torna espelho". Essa anotação também aparece no fólio 270 com alguma alteração: "o mar que ainda é espelho". No fólio 180, ao analisar o poema $O$ homem e o mar, Benveniste transcreve um verso do poema, "O mar é teu espelho", e anota para esse verso: "Aqui o tema complica o tema do reflexo; de um lado o homem, de outro o mar, mas o mar como reflexo e duplo do homem". Como conclusão da análise, Benveniste escreve: 
[...] O mar é o homem, tudo nele responde a

sua essência, mas ela é também o espelho do homem, onde o homem contempla

onde este aqui eneontra e afronta sua imagem. O homem

preza o mar e combate-o. Sua luta é

aquela de gladiadores implacáveis, o homem e seu duplo, unidos pelo gosto da carnificina e da morte. (18, f $\mathrm{f}^{\mathrm{o}} 7 / \mathrm{f}^{\mathrm{o}} 180$ ).

O mar é espelho; o mar é o espelho do homem; o mar é o homem, pois tudo nele responde a sua essência, registra Benveniste. Ao que ele escreve: o homem contempla e afronta sua imagem no espelho. Nesse sentido, o homem preza o mar e o combate, ou, poderíamos dizer, o homem preza e combate a sua imagem, ou, ainda, o homem preza e combate $o$ seu duplo?

Além do mar, os lagos são apresentados como espelhos no fólio 270 :

$[\ldots]$

Baudelaire só se interessa pelos lagos que são ainda espelhos ou transparências, pelas grandes águas em movimento, e enfim e sobretudo pelo mar, não denominado de outra forma (oceano também mas bem menos e de modo meio desfavorável), o mar que é ainda caro ao homem livre

espelho, e também doce profundeza, envolvente, canção de ninar, que leva os navios e contém segredos. $[\ldots]\left(22, f^{\mathrm{o}} 18 /\right.$ f $\left.^{\mathrm{o}} 270\right)$. 
No fólio 60, Benveniste escreve:

Nota

Baudelaire qu em suas imagens

recorre frequentemente ao mar mergulho

(navio, vela, nado, etc.) e

por outro lado, chama segui-

damente $o$ aniquilamento, morte

e seguido evoca a profundeza, mergulho

ou sono, não emprega

nenhum exemplo de:

naufrágio, submersão, afundamento,

desastre.

afogamento é só metafórico em B.

Ao contrário

sepultar, enterrar, caixão, sepultura são

bem atestados, com o cortejo de decomposição

de vermes e de deterioração.

B. não vê a morte em meio

às águas, na submersão onde o corpo desaparece

Jamais « os afogados dormindo a descer aos recuões » (Rimbaud) foi

possível em Baudelaire.

$\left(12, \mathrm{f}^{-} 8 / \mathrm{f}^{\mathrm{o}} 60\right)$.

Benveniste escreve que Baudelaire, desaparecendo". O linguista cita um em suas imagens, recorre frequentemen- verso de Rimbaud para dizer que o que te ao mar; no entanto, não há exemplo encontramos nesse poeta não é possível algum de "naufrágio, afundar, soçobrar, em Baudelaire. O linguista volta à quesdesastre. [...] B. não prevê a morte no tão de Rimbaud no fólio 47, cujo título é seio da água, na submersão ou o corpo As imagens do mar: 
Jamais Baudelaire evoca um afogado: (o verso de Rimbaud "os afogados dormindo a descer aos recuões" ełe ele é justamente o oposto de sua concepção de mar). Ele jamais pensa no mar como uma estadia de morte. Os animais marinhos lhe são desconhecidos: uma única vez "e dormir no esquecimento como um tubarão na onda"; peixe está ausente de seu vocabulário. Comparar a frequência dos pássaros, dos animais, em direção da terra.

$[\ldots]$

sombras

nas sombras abismos ${ }^{2}$

Ou Baudelaire não emitiu reteve as alegrias que jazem no fundo do oceano

onde "muita joia dorme enterrada / na escuridão e esquecimento / bem longe das picaretas e das sondas" com a ambiguidade picaretas/ sondas referindo-se indiferentemente aos dois elementos. Comparemos então nas Litanias (CXX) "onde dorme enterrado o povo dos metais" e veremos que a profundeza das terras é unicamente para ele rica e geradora de imagens. (10, $\left.\mathrm{f}^{\circ} 14 / \mathrm{f}^{\circ} 47\right)$.

${ }^{2}$ abissal > abismos (?). (LAPLANTINE, 2008, p. 101).

O que vemos aqui é que, diferentemente de Rimbaud, o mar, para Baudelaire, não é lugar para a morte, mas lugar para o reflexo do homem, ou seja, para a vida. Não há aqui menção às profundezas do mar como geradora de imagens, somente as profundezas da terra o são. O que interessa, pois, é a superfície do mar porque evoca o reflexo.
No fólio 217, Benveniste apresenta cinco palavras sob o título mar: "aparelhar um navio, cavernas basálticas, barra, capitão, pavilhão”. Estaria o linguista atrás de outras palavras que evocassem o mar e por extensão a imagem do espelho? Não sabemos, pois não há pistas que nos encaminhem a isso.

O mar volta a partir do título metáforas - líquidas no fólio 96 :

(citar)

Importância do verbo derramar e de afundar

de deslizar

verter-se.

Depois os grandes líquidos estendidos

mar - oceano - rios - águas - ondas

e por atração as imagens marítimas

porto velas mastros fragatas, marinheiros barco navio nau $\left(14, \mathrm{f}^{\mathrm{o}} 17 / \mathrm{f}^{\mathrm{o}} \mathrm{96}\right)$. 
Novamente é apresentada uma lista de metáforas da água no fólio 71:

metáforas da água

- nadar

- mergulhar

- afundar

- deslizar

- flutuar (13, fo 11/ fo 71$)$.
Em busca da imagem do espelho, e do mar como espelho, Benveniste talvez estivesse realizando um levantamento das metáforas que pudessem remeter a essa imagem.

No fólio 85, assim como o espelho, o metal é problematizado como uma matéria vivente:

se reúnem, agem

As matérias vivem 'e formam as unidades

- o povo dos metais.

- os puros espelhos que tornam todas as coisas mais belas

— os fragmentos de ouro estrelam seus olhos (14, $\mathfrak{f}^{\circ} 6 / \mathrm{f}^{\mathrm{o}} 85$ ).

"Povo dos metais" é um trecho de um dos versos do poema As litanias de Satã (CXX): "Tu cujo olhar desvela os fundos arsenais/ Onde sepulto dorme o povo dos metais" (BAUDELAIRE, 2006, p. 397). O que vemos nesse excerto é que os metais e o ouro, como extensão do metal, aparecem como matérias que vivem, reúnem-se e agem. Num primeiro momento, Benveniste escreveria "as matérias vivem e formam as unidades" ao que ele risca e escreve "agem". Pare- ce-me aqui que o metal age como imagem e não forma uma imagem. No entanto, nada mais é referido acerca desse aspecto em relação ao metal. Qual seria a diferença entre agir como imagem e formar uma imagem?

No fólio 239, Benveniste procede a um levantamento de termos - pelos números, parece que esse levantamento não foi concluído - relacionados à imagem do metal, cujo título é Metais:

\begin{tabular}{lll}
\multicolumn{5}{c}{ pedras } \\
aço & ágata \\
ferro & opala & \\
ouro & diamante & \\
prata & rubis $(1)$ \\
joia & safira (1) pérola $\quad\left(21, \mathrm{f}^{0} 31 / \mathrm{f}^{\mathrm{o}} 239\right)$.
\end{tabular}


Também a luz comparece na escrita de Benveniste. No fólio 97, o linguista procede a um levantamento de palavras que fazem referência às grandes emanações luminosas. Destas, ele anota que "claro" é fortemente valorizado, aparecendo 51 vezes em As Flores do Mal. Também registra, mas sem quantificar, "farol", "raio", "reflexo", "refletir", "luminoso", entre outros vocábulos. Estaria a luz, a partir do "reflexo", para a imagem do espelho?

Em relação à luminosidade, a "pupila" aparece, no fólio 31, como uma "palavra-chave":

$$
\text { luminoso }
$$

A pupila é o centro do olho contemplado. Baudelaire olha

longamente os olhos dos gatos, os olhos das mulheres, os olhos da Beleza $\left(9, \mathrm{f}^{\circ} 8 / \mathrm{f}^{\mathrm{o}} 31\right)$.
No fólio 86, cujo título é Imagem, Benveniste anota "Toda beleza tende a uma figura de imobilidade", remetendo ao poema $A$ Beleza, também citado no fólio 31. A última estrofe desse poema versa "Pois que disponho, para tais dóceis amantes,/ De um puro espelho que idealiza a realidade:/ O olhar, meu largo olhar de eterna claridade" (BAUDELAIRE, 2006, p. 153). Seria o olhar também um espelho? Estaria a luz para o reflexo do espelho? E, ainda, seria o metal, como material que vive, reúne-se e age, igualmente um espelho? Assim, não estaria em todas as notas Benveniste atrás da imagem do espelho? Seria essa a articulação mencionada pelo linguista no fólio 81 ?

Voltemos aos fólios 42, 97 e 269 a partir de três excertos:

[...] Baudelaire não pode se encontrar senão em igualdade; não há para ele o complementar: ele tem que ser idêntico. Somente o espelho ou o ser-espelho pode fornecer-lhe o parceiro desejado um outro ele mesmo, ao pé da letra.

[...] Importância do espelho o outro, o semelhante, o amado - ou ou a si mesmo que se contempla

Tudo então em Baudelaire é correspondência e tudo tende a realizar uma harmonia:

«Correspondências » e «Harmonia » são justamente títulos de poemas.

Daí a importância da noção de espelho:

o homem e o mundo se refletem um no outro. [...]

As coisas

não existem por si mesmas. Elas só são dadas

por e para sentimentos que suscitam no homem em suas

isto é ainda para as correspondências 
Parece-me que a imagem espelho revela uma importante correspondência: a correspondência entre o homem e o mundo, o homem e as coisas do mundo, o homem e seu duplo. Nesse sentido, o espelho coloca em cena a própria correspondência. Correspondência esta que se harmoniza. Isso porque em As Flores do $M a l$ as coisas do mundo não existem por si mesmas: elas só existem por e para sentimentos que suscitam no homem. Ou seja, não há como separar as coisas do mundo e o homem, pois esses dois sistemas estão conectados na poesia de Baudelaire. E, dessa forma, eles se harmonizam. Esta é a articulação do espelho.

E é por esse viés que Benveniste escreve sobre o fundamento da poética baudelaireana:

Fundamento da poética baudelaireana

Toda atitude de Baudelaire em relação ao mundo, à vida, ao homem encontra sua unidade neste princípio: Baudelaire quer colocar em correspondência e em harmonia a natureza do mundo e a natureza do homem

A natureza do homem, é tudo que a civilização, a sociedade, a miséria, a maldade sufocam ou deformam: a sensibilidade profunda, a liberação dos sentidos, as forças emotivas, a beleza instintiva, o acordo dos corações.

A natureza do mundo, é o aspecto oculto, profundo das coisas, aquele que também encontra no homem seu eco ("lua, água sonora, noite abençoada... sua pura melancolia é o espelho de meu amor" - ou ao contrário o balanço das vagas, os movimentos do ar": (22, fo $16 /$ fo 268$)$.

A imagem, então, a partir da palavra poética, coloca em correspondência o homem e o mundo. Pela palavra, o homem olha o mundo e se corresponde: a palavra que diz do mundo, diz do homem, diz de sua emoção e de sua experiência. A correspondência é, então, o princípio que estrutura o universo poético baudelairiano.

\section{Considerações finais}

Dessons (2008) esclarece que a partir da poesia moderna não podemos mais pensar a imagem como um privilégio da poesia: a imagem é um elemento constitutivo da linguagem. E é a partir da escrita surrealista que a imagem, desde Aristóteles vinculada à represen- 
tação, é entendida como enunciação. Estaria Benveniste no final dos anos 1960 justamente problematizando que a imagem diz da linguagem e, por isso, da experiência humana? $\mathrm{Ou}$, ainda, o que as correspondências dizem do estudo empreendido por Benveniste?

Voltemos ao fólio 15:

\section{[...]}

(Nota: procurar as imagens criadoras, os esquemas que se engendram, e ver como eles se produzem e que estrutura eles constituem).

[...] $\left(8, \mathfrak{f}^{\mathrm{o}} 5 / \mathrm{f}^{\mathrm{o}} \mathbf{1 5}\right)$.

No percurso de pesquisa que compartilhei aqui, entendo que Benveniste escreveu neste fólio justamente sobre o que objetivava em seu estudo. O linguista procurou por imagens criadoras, tendo realizado diferentes levantamentos e encontrado variadas palavras, dentre elas "espelho", "mar", "lago", "metal" e "luz". A partir dessas palavras, pude observar que a imagem do espelho, de certa forma, engendra as demais a partir da correspondência entre o homem e o mundo. Nesse sentido, o grande esquema de As Flores do Mal seriam as correspondências. Benveniste parecia, então, atrás de metáforas e comparações que também colocassem em cena essa correspondência. Assim, parece-me que a estrutura que os esquemas constituem é a da correspondência mesmo, que coloca em harmonia no discurso da língua de Baudelaire o homem e o mundo. Correspondências que estão para a relação de homologia entre sistemas semiológicos distintos.
Nesse sentido, a escolha reveladora de imagens é uma possibilidade de estudo semiológico de uma obra literária: de uma obra e não das obras - essa possibilidade está somente em Baudelaire. Dito de outro modo, a linguagem poética de Baudelaire convoca uma semiologia de segunda geração: problematizar essas correspondências está para além do signo saussuriano como princípio único. É preciso, pois, adentrar em outro universo, em outro território, o da semântica da enunciação, porque é em e por Baudelaire que essas correspondências são vivenciadas. 


\section{"The perfumes, colours and sounds correspond": Benveniste and the search for the creative image in Baudelaire}

\begin{abstract}
In 1992, Émile Benveniste's manuscripts about poetic language were disclosed and generated what today is known as Baudelaire Dossier. This study aims to verify how Benveniste's writing in the dossier can be delineated as a semiological study of a work. The corpus are 159 folios that let you see terms and procedures ruminated on the writing of Benveniste. The results point out that the particularity and singularity of Baudelaire's discourse are due to both the image of the mirror, which engenders other creative images. The correspondence is thus the principle structuring Baudelaire's poetic universe.
\end{abstract}

Keywords: Semiology. Baudelaire Dossier. Creative image.

\section{Nota}

1 Em 5.2.2, deter-me-ei especificamente na ideia de ícone.

\section{Referências}

BAUDELAIRE, C. As Flores do Mal. Trad. Ivan Junqueira. Rio de Janeiro: Nova Fronteira, 2006.

BENVENISTE, É. Últimas aulas no Collège de France (1968 e 1969). Edição estabelecida por Jean-Claude Coquet e Irène Fenoglio. Trad. Daniel Costa da Silva et al. São Paulo: Editora Unesp, 2014.

Baudelaire. Présentation et transcription de Chloé Laplantine. Limoges: Lambert-Lucas, 2011.
[1969] Sémiologie de la langue. In: [1974]. Problèmes de linguistique générale, 2. Paris: Éditions Gallimard, 2008. p. 43-66.

. [1969] Semiologia da língua. In: [1974]. Problemas de lingüistica geral II. Campinas: Pontes, 1989. p. 43-67.

DESSONS, G. Introduction à l'analyse $d u$ poème. Paris : Armand Colin, 2008.

FENOGLIO, I. Manuscritos de linguistas e genética textual: quais os desafios para as ciências da linguagem? Exemplo através dos "papiers" de Benveniste. Tradução Simone de Mello de Oliveira, Verli Petri da Silveira, Zélia Maria Viana Paim. Santa Maria: UFSM, PPGL-Editores, 2013.

Benveniste auteur d'une recherche inachevée sur "le discours poétique " et non d'un «Baudelaire ». Semen, n. 33, Franche-Comté, avril, 2012, p. 121-161.

Les notes de travail d'Émile Benveniste: où la pensée théorique naît via son énonciation. Langage et société, n. 127, 2009, p. 23-49.

FLORES, V. do N. Introdução à teoria enunciativa de Émile Benveniste. São Paulo: Parábola, 2013.

LAPLANTINE, C. Présentation. In: BENVENISTE, É. Baudelaire. Edição Chloé Laplantine. Limoges: Lambert-Lucas, 2011a. Émile Benveniste, l'inconscient et le poème. Limoges: Lambert-Lucas, 2011b.

La poétique d'Émile Benveniste. In: MARTIN, S. Émile Benveniste: pour vivre langage. Mont-de-Laval: IUFM Basse-Normandie, 2009. p. 25-38.

. Annexes. Fascicule 1 - Transcription diplomatique et reproduction des manuscrits inédits d'une poétique de Baudelaire par Emile Benveniste. Tese (Doutorado). Université Paris 8. Saint-Denis. 2008b. Disponível em: <https://hal.archives-ouvertes. fr/tel-01228022/file/annexesLAPLANTINE. pdf $>$. Acesso em: 13 maio 2012. 